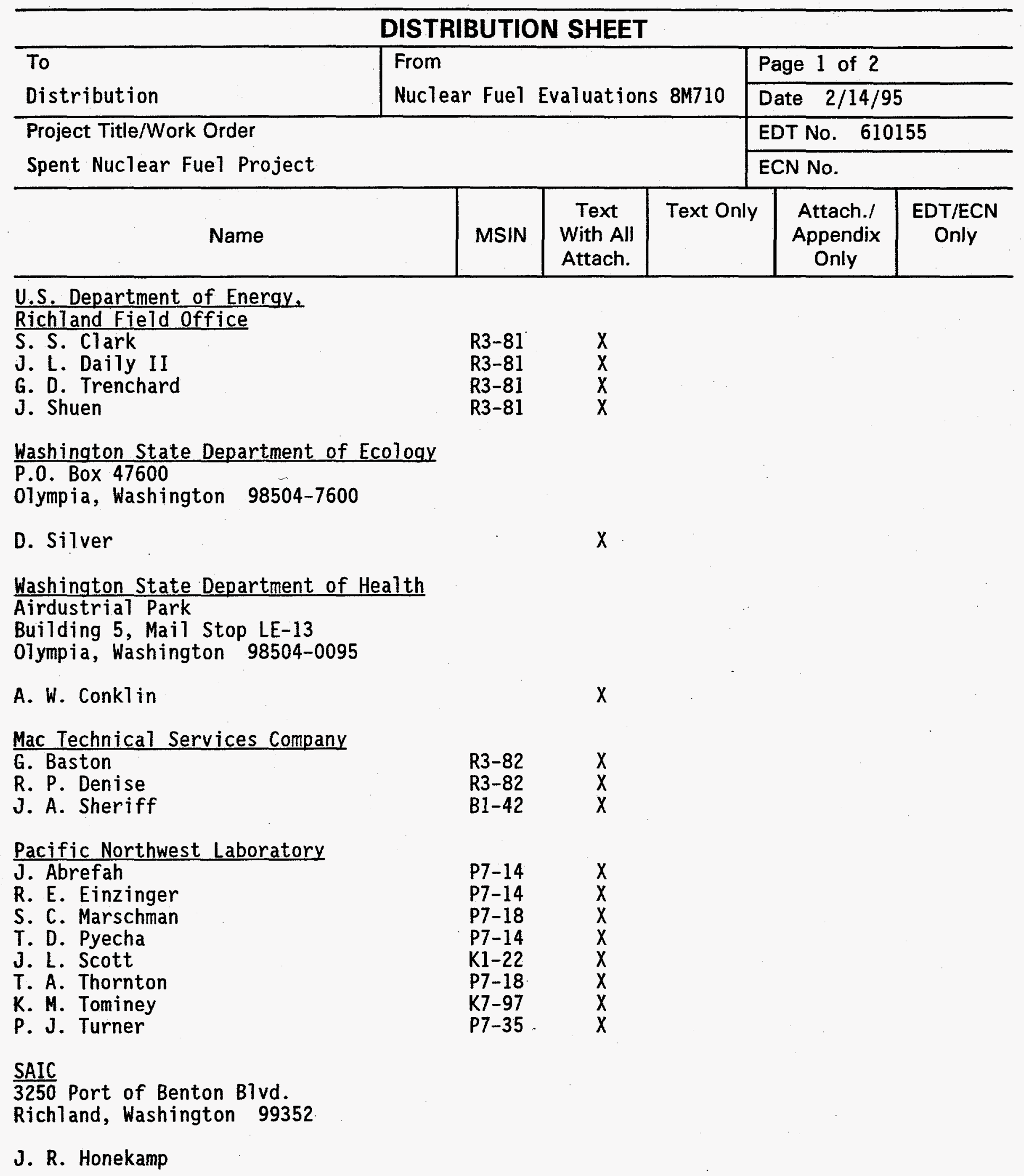


DISTRIBUTION SHEET

\begin{tabular}{|c|c|c|c|c|c|}
\hline To & \multirow{2}{*}{\multicolumn{3}{|c|}{$\begin{array}{l}\text { From } \\
\text { Nuclear Fuel Evaluations 8M710 }\end{array}$}} & \multicolumn{2}{|l|}{ Page 2 of 2} \\
\hline Distribution & & & & \multicolumn{2}{|c|}{ Date $2 / 14 / 95$} \\
\hline \multirow{2}{*}{\multicolumn{4}{|c|}{$\begin{array}{l}\text { Project Title/Work Order } \\
\text { Spent Nuclear Fuel Project }\end{array}$}} & \multicolumn{2}{|c|}{ EDT No. 610155} \\
\hline & & & & \multicolumn{2}{|l|}{ ECN No. } \\
\hline Name & MSIN & $\begin{array}{l}\text { Text } \\
\text { With All } \\
\text { Attach. }\end{array}$ & Text Onl & $\begin{array}{l}\text { Attach./ } \\
\text { Appendix } \\
\text { Only }\end{array}$ & $\begin{array}{l}\text { EDT/ECN } \\
\text { Only }\end{array}$ \\
\hline
\end{tabular}

Westinghouse Hanford Company

D. W. Bergmann

A. E. Bridges

B. S. Carlisle

S. A. Chastain

R. G. Cowan

J. C. Fulton

J. R. Frederickson

E. W. Gerber

L. H. Goldmann

S. L. Hecht

A. T. Kee

L. A. Lawrence

B. J. Makenas

R. L. McCormack

C. R. Miska

R. P. Omberg

A. L. Pajunen

J. Perez-Carter

R3-86

L5-01

X3-71

L5-01

R3-86

R3-85

R3-86

R3-86

R3-86

L5- 01

R3-86

L5- 01

[5-01

R3-86

R3-86

R3-86

H5-49

L5-01

A. L. Pitner

J. P. Schmidt

[5-01

$\times 3-73$

P. K. Shen

D. W. Smith

D. J. Trimble

J. W. Weber

R3-87

R3-85

L5- 01

L5-01

R3-86

L8-04

L8-07

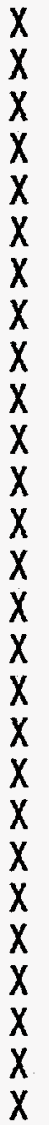

OSTI (2)

Files

) 


\begin{tabular}{|l|l|}
\hline $\begin{array}{l}\text { 2. To: (Receiving Organization) } \\
\text { Distribution }\end{array}$ & $\begin{array}{l}\text { 3. From: (originating Organization) } \\
\text { Nuclear Fuel Evaluations } \\
8 M 710\end{array}$ \\
\hline $\begin{array}{l}\text { 5. Proj./Prog./Dept./Div.: } \\
\text { SNFP }\end{array}$ & $\begin{array}{l}\text { 6. Cog. Engr.: } \\
\text { L. A. Lawrence }\end{array}$ \\
\hline
\end{tabular}

8. Originator Remarks:

For approval and information -- Data Quality Objectives for the Initial $K$ West Fuel Examinations

11. Receiver Remarks:
4. Related EDT NO.:

7. Purchase Order No.:

$N / A$

9. Equip./Component No.: N/A

10. System/Bldg./Facility: $\mathrm{K}$ Basins/100 K

12. Major Assm. Dwg. No.: $N / A$

13. Permit/Permit Application No.: N/A

14. Required Response Date:

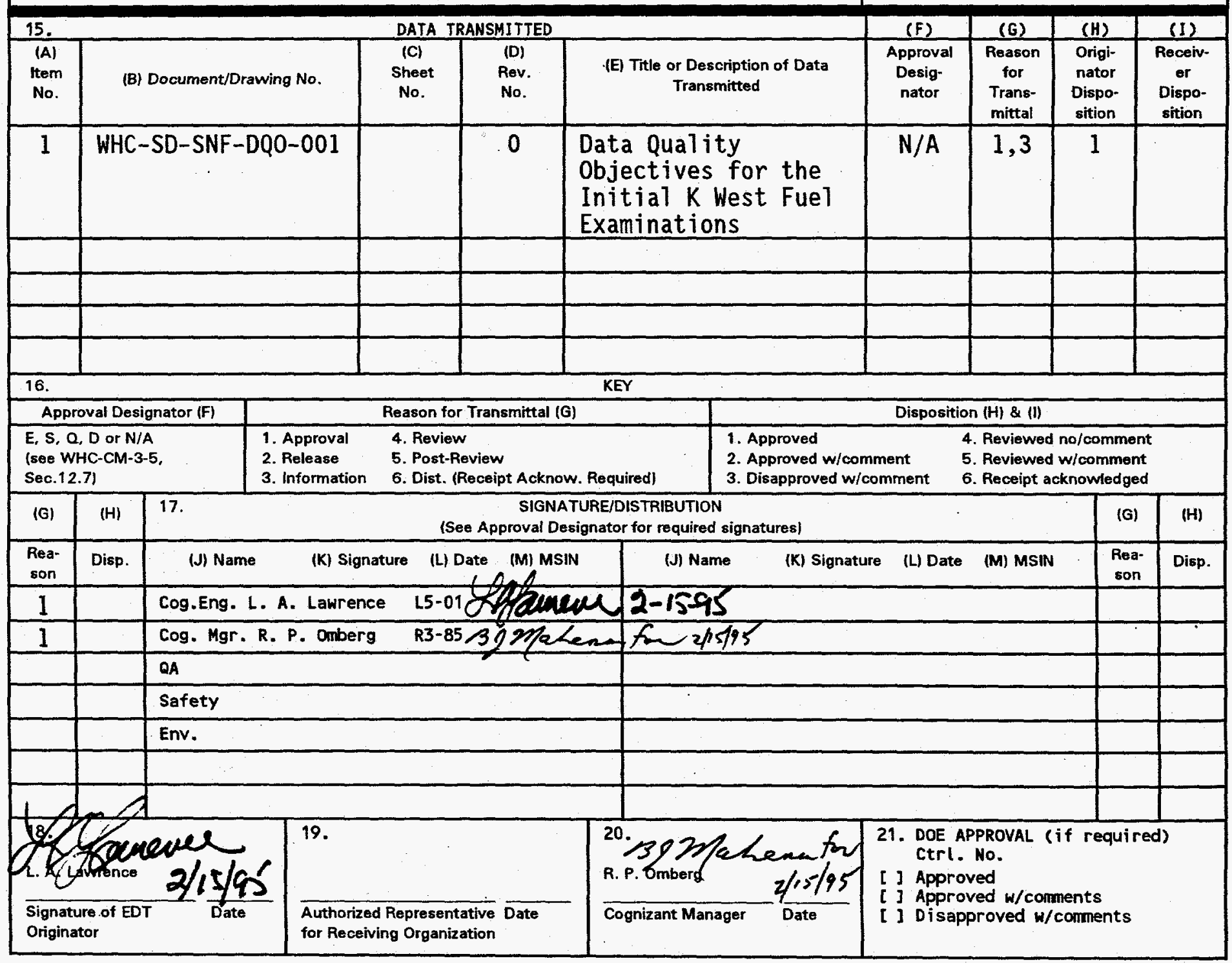




\section{DISCLAIMER}

Portions of this document may be illegible in electronic image products. Images are produced from the best available original document. 


\section{RELEASE AUTHORIZATION}

Document Number: WHC-SD-SNF-DQ0-001, REV. 0

Document TItIe: DATA QUALITY OBJECTIONS FOR THE INITIAL $K$ WEST FUEL EXAMINATIONS

Release Date: 2/16/95

This document was reviewed following the procedures described in WHC-CM-3-4 and is:

\section{APPROVED FOR PUBLIC RELEASE}

WHC Information Release Administration Specialist:

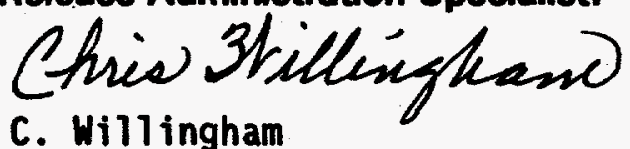

C. Willingham

TRADEMARK DISCLAIMER. Reference herein to any specific commercial product, process, or service by trade nane, tradenark, manufacturer, or otherwise, does not necessarily consti tute or imply its endorsement, recomiendation, or favoring by the United States Governient or any agency thereof or its contractors or subcontractors.

This report has been reproduced from the best aveilable copy. Available in peper copy and microfiche. Printed in the United States of Americs. Available to the U.S. Departiment of Energy and its contractors from:

U.S. Department of Energy

Office of Scientific and Technical Information (OSTI)

P.0. Box 62

Dak Ridge, TM 37831

Telephone: (615) 576-8401

Available to the public fran:

U.S. Depertment of Commerce

Netional Technical information Service (Wris)

5285 Port Royal Roed

Springfield, VA 22161

Telephone: (703) 487-4650 


\begin{tabular}{|l|l|c|}
\hline $\begin{array}{l}\text { 2. Title } \\
\text { Data Quality Objectives for the Initial K West } \\
\text { Fuel Examinations }\end{array}$ & $\begin{array}{c}\text { 3. Number } \\
\text { WHC-SD-SNF-DQ0-001 }\end{array}$ & 0 \\
\hline $\begin{array}{l}\text { 5. Key Words } \\
\text { DQO, 105-K West, Fuel Examinations, SNFP }\end{array}$ & $\begin{array}{l}\text { 6. Author } \\
\text { Signitle }\end{array}$ \\
\hline
\end{tabular}

7. Abstract

The Data Quality Objectives (DQOS) were established for the examinations of the first group of fuel samples shipped from the $K$ West Basin to the Hanford 327 Building hot cells for examinations to support the Path Forward recommended to solve the safety and environmental concerns associated with the deteriorating fuel in the $K$ Basins. A separate $D Q O$ will be prepared for each future shipment of samples to the hot cells. The material stored in the $K$ West Basin must ultimately be removed from the basin and placed in a stable storage configuration until it can be disposed of in a repository. The condition of the fuel in the closed canisters is a major uncertainty for any of the proposed actions.

The major question to answer is what are the conditions of the materials in the closed canisters? The data to be gathered during the canister opening, handling, transport, associated hot cell handling, and examinations will also support decisions related to the Path Forward primarily in areas of transportation and the Multi-Canister Overpack (MCO) design.

8. RELEASE STAMP

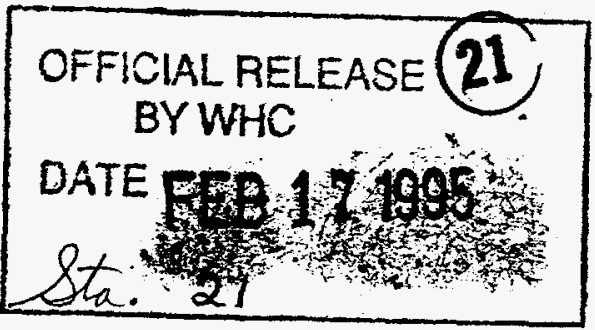




\title{
DATA QUALITY OBJECTIVES FOR THE INITIAL $K$ WEST FUEL EXAMINATIONS
}

\author{
L. A. Lawrence \\ Westinghouse Hanford Company
}

T. A. Thornton, J. Abrefah

Pacific Northwest Laboratory

February 1995

\section{DISCLAIMER}

This report was prepared as an account of work sponsored by an agency of the United States Government. Neither the United States Government nor any agency thereof, nor any of their employees, makes any warranty, express or implied, or assumes any legal liability or responsibility for the accuracy, completeness, or usefulness of any information, apparatus, product, or process disclosed, or represents that its use would not infringe privately owned rights. Reference herein to any specific commercial product, process, or service by trade name, trademark, manufacturer, or otherwise does not necessarily constitute or imply its endorsement, recommendation, or favoring by the United States Government or any agency thereof. The views and opinions of authors expressed herein do not necessarily state or reflect those of the United States Government or any agency thereof. 
Document Title: DATA QUALITY OBJECTIVES FOR THE INITIAL $K$ WEST FUEL EXAMINATIONS

Approved by:

Approved by:

Approved by:

Approved by:

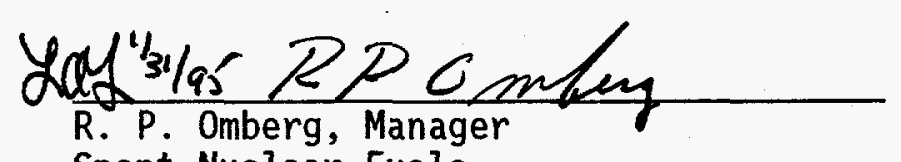

Spent Nuclear Fuels

Characterization Program

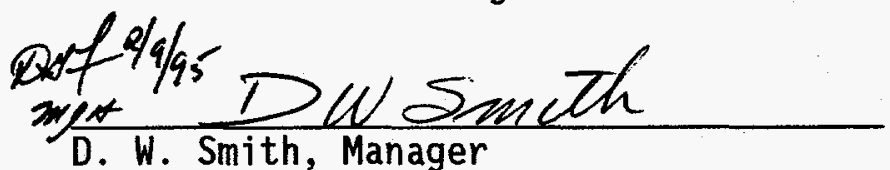

D. W. Smith, Manager

SNFP Quality Assurance

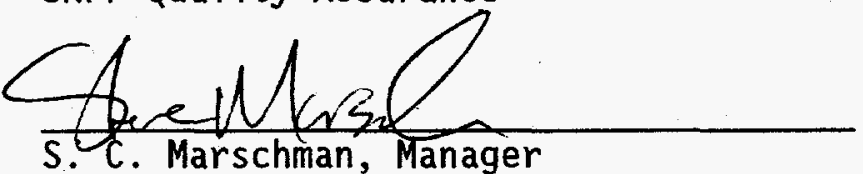

Fuels and Dry Storage

PNL Spent Nuclegr Fuels Project

G. D. Trenchard, Acting Manager

Interim Storage and Disposition Program

U.S. Department of Energy

Richland Office

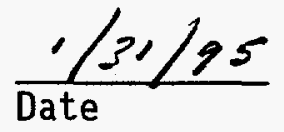

$\frac{2-9-95}{\text { Date }}$

$\frac{|-3|-95}{\text { Date }}$

$2 \cdot 15 \cdot 95$

Date 
WHC-SD-SNF-DQ0-001, Rev. 0

\section{EXECUTIVE SUMMARY}

The Data Quality Objectives (DQOS) were established for the examinations of the first group of fuel samples shipped from the $K$ West Basin to the Hanford 327 Building hot cells for examinations to support the Path Forward recommended to solve the safety and environmental concerns associated with the deteriorating fuel in the K Basins. A separate $D Q 0$ will be prepared for each future shipment of samples to the hot cells. The material stored in the $K$ West Basin must ultimately be removed from the basin and placed in a stable storage configuration until it can be disposed of in a repository. The condition of the fuel in the closed canisters is a major uncertainty for any of the proposed actions.

The major question to answer is what are the conditions of the materials in the closed canisters? The data to be gathered during the canister opening, handling, transport, associated hot cell handling, and examinations will also support decisions related to the Path Forward primarily in areas of transportation and the Multi-Canister Overpack (MCO) design. In the areas of shipping and transportation the following questions have been raised.

1. Will the MCOS be shipped full of water or will the water be drained?

2. What will the gas inventory be during shipping?

3. Will the shipment be in vented or sealed MCOs?

4. Will the shipment be in a horizontal or vertical position?

Similarly there are related questions for the MCO design such as:

5. What materials should the MCO be fabricated from?

6. What are the MCO vent and possible gas purge requirements?

7. What is the expected continued degradation of fuel material in the MCO? 
The 1 imited scope represented by these samples and examinations will not provide definitive justification for all the decisions that must be made. However, the data input when combined with other data along with parallel design and analysis provide the basis for the decisions. The applicability of the data collected is also subject to scheduler constraints. Decisions may by necessity be made before sufficient data is obtained from these examinations. In these cases, the data collected may only be confirmatory.

The following data inputs are available during the examinations of the first shipments of fuel to the hot cells. All the in-basin activities associated with the canister movement, opening, element removal, and loading of the Single Fuel Element Containers (SFECS) will be monitored and recorded on video. Gas pressure buildup will be measured in the SFECs before they are shipped to the hot cells by means of a special 1id. The condition of the fuel elements will be closely monitored during all the examination steps in the hot cells. The hot cell examinations will be conducted in an air environment in the hot cells. These examinations include visual examinations and photography, dimensional characterization, weight and density, metallography and controlled atmosphere and temperature testing of fuel samples for combustibility. The data to be collected are connected to the decisions to be made for transportation and the MCOS through the use of logic diagrams.

The variables affecting fuel during the extended underwater storage were identified and the types of samples required for the initial examinations of fuel for the $K$ West Basin were defined. 
WHC-SD-SNF-DQO-001, Rev. 0

\author{
CONTENTS
}

1.0 INTRODUCTION ......................... 5

2.0 DATA QUALITY OBJECTIVE STEP 1: STATEMENT OF PROBLEM $\ldots \ldots \ldots$

3.0 DATA QUALITY OBJECTIVE STEP 2: IDENTIFY THE DECISIONS . . . . . 7

4.0 DATA QUALITY OBJECTIVE STEP 3: IDENTIFY THE INPUTS $\ldots \ldots \ldots$

4.1 VISUAL/VIDEO DURING IN-BASIN EXAMINATIONS . . . . . . . . 9

4.2 GAS GENERATION MEASUREMENTS . . . . . . . . . . . . . . 14

4.3 VISUAL/VIDEO DURING HOT CELL EXAMINATIONS . . . . . . . . 14

4.4 DIMENSIONAL CHARACTERIZATION .............. 15

4.5 ELEMENT WEIGHT AND DENSITY . . . . . . . . . . . . . 15

4.6 METALLOGRAPHY . . . . . . . . . . . . . . . . . . . . . 15

4.7 FURNACE TESTING . . . . . . . . . . . ..... 16

5.0 DATA QUALITY OBJECTIVE STEP 4: DECISION BOUNDARIES $\ldots \ldots \ldots$

6.0 DATA QUALITY OBJECTIVE STEPS 5 AND 6 : DECISION RULES
AND ACCEPTABLE LIMITS ON DECISION ERROR ........ 17

7.0 DATA QUALITY OBJECTIVE STEP 7 : OPTIMIZE . . . . . . . 17

8.0 SAMPLE SELECTION . . . . . . . . . . . . . 17

8.1 VARIABLES INFLUENCING FUEL DEGRADATION ........ 18

8.2 K WEST SAMPLES SELECTED FOR THE INITIAL FUEL EXAMINATIONS $\ldots 20$

9.0 REFERENCES ....................... 21 
WHC-SD-SNF-DQ0-001, Rev. 0

\section{DATA QUALITY OBJECTIVES FOR THE INITIAL $K$ WEST FUEL EXAMINATIONS}

\subsection{INTRODUCTION}

The Data Quality Objectives (DQ0s) were established for the examinations of the first group of fuel samples shipped from the $K$ West Basin to the Hanford 327 Building hot cells for examinations (Lawrence 1994). The DQO process was employed to ensure the planned examinations fully support the Path Forward recommended to solve the safety and environmental concerns associated with the deteriorating fuel in the K Basins (Fulton 1994).

The initial focus of the examinations covered in this DQO is establishing the condition of the fuel in the closed canisters in $K$ West, the response of the fuel when exposed to basin water when the canisters are opened, and the fuels behavior during handling and examination in the air atmosphere hot cells. The Path Forward activities associated with transportation, MCO design, staging, and stabilization require some understanding of the condition of the fuel in the closed canisters. The canisters in $K$ West have not been opened for inspection or examinations since they were placed in the basin in the mid 1980's. The condition of the fuel in these closed canisters was identified as a major project uncertainty during the discussions at the Hanford Forum on Spent Nuclear Fuels Characterization in March 1994. There are data in the literature that suggests fuel in the closed canisters may have undergone more extensive hydriding and deterioration in the presence of deoxygenated water compared to the fuel degradation visible in $K$ East with open canisters.

The examinations will help establish what types of fuel conditions could represent the worst case for the Path Forward, establish a sampling strategy in support of additional detailed characterization dictated by the evolution of the Path Forward activities and support future analyses for final disposition of the fuel.

The data obtained from these examinations during canister opening, handling, transport, hot cell handling, and examinations also supports decisions related to the Path Forward activities. The limited scope represented by the samples and the data collected will not provide definitive justffication for all the decisions that must be made concerning transportation and the MCO design. The data inputs when combined together with other data along with parallel design and analyses provide the basis for a design decision. These data also provide input for the other activities within the Path Forward scenario however, the decisions for staging, stabilization, and long term storage are not as immediate and as integral as those for transportation and the MCO design.

The applicability of the data collected in this examination to the Path Forward activities is also subject to the scheduler constraints of the Path Forward. Decisions related to transportation and the co-dependent MCO 
WHC-SD-SNF-DQ0-001, Rev. O

design may by necessity have to be made before sufficient data is obtained from the fue 7 examination efforts. In these cases the data collected may only be confirmatory in nature justifying there is sufficient latitude incorporated into the corresponding decision for the observed fuel condition or behavior.

A detailed Path Forward decision schedule is unavailable at this time to correlate with the examination schedules for these samples. Therefore, it is uncertain what data will be available from these examinations to support the required Path Forward decisions.

\subsection{DATA QUALITY OBJECTIVE STEP 1: STATEMENT OF PROBLEM}

The radiological pathway for fuel and fission products to the environment in the $K$ Basins must be severed. The material in $K$ West in the closed canisters is generally isolated from the basin water however, failures of the canister seals have resulted in increases in the radionuclide inventory in the basin water (Burke 1994). The material must ultimately be removed from the basin and placed in a stable storage configuration until it can be disposed of in a repository.

Several methods have been proposed to address the problem and they all involve moving and handling either the complete canisters or the individual fuel elements stored in the canisters. The condition of the fuel in the closed canister is a major uncertainty for any of the proposed solutions.

The recommended Path Forward (Fulton 1994) for the $K$ Basins includes placing the canisters in MCOs and shipping them to a staging and storage facility for short term storage. The MCOs will then be transferred to the conditioning facility. Following conditioning the MCOs will be returned to the staging and storage facility for long term interim storage.

Samples are scheduled to be shipped to the hot cells for examination March 31 , 1995. Nondestructive examinations are projected to be completed in June and initial metallographic examinations completed by the end of FY 1995 . Furnace testing for material combustibility will be completed in early FY 1996. The present draft Path Forward schedule calls for the Level 3 function and requirements to be completed for the MCO by the end of the First Quarter FY 1996 (Goldmann 1995). Therefore, these limited scope examinations will have some input to the decision process for the MCO functions and requirements as well as the fabrication specifications which are scheduled to be completed by the end of FY 1996.

Table 1 .

Stakeholders for the initial examinations of $K$ West fuel are listed in 
Table 1. Stakeholders for Initial $\mathrm{K}$ West Fuel Shipments.

\begin{tabular}{||l|l|}
\hline \multicolumn{1}{|c|}{ Function } & Individual Point of Contact \\
\hline 1. Path Forward & $\begin{array}{l}\text { MCOs--L.H. Goldmann } \\
\text { Transportation--A.T. Kee } \\
\text { Stabilization--A.L. Pajunen }\end{array}$ \\
\hline 2. Basin Operations & B.S. Carlisle \\
\hline 3. Regulatory Integration & V.C. Hoeffer \\
\hline 4. Technical Oversight & J.C. DeVine \\
\hline 5. K Basin Engineering & J.P. Schmidt \\
\hline 6. Quality Assurance & D.W. Smith \\
\hline 7. Analytical Laboratory Support & J.R. Cooper \\
\hline 8. RL & G.D. Trenchard \\
\hline 9. Characterization & $\begin{array}{l}\text { WHC--R.P. Omberg } \\
\text { PNL--S.C. Marschman }\end{array}$ \\
\hline
\end{tabular}

\subsection{DATA QUALITY OBJECTIVE STEP 2: IDENTIFY THE DECISIONS}

The major question to be answered by these examinations is what are the conditions of the materials in the closed canisters specifically those fuel elements which have broken or breached cladding. These examinations will also provide data to address decisions related to the Path Forward in the areas of transportation and the MCO. Development of the shipping route and the MCO design are intrinsically tied together as is the MCO design with the staging area where the MCOs will be placed before they are stabilized. been raised:

In the area of shipping and transportation the following questions have

1. Will the MCOS be shipped full of water or will the water be drained out before shipment to the staging area? There is currently a high probability that the MCOs will be full of water.

2. What will the gas inventory, especially hydrogen, be in the MCOs during shipping? The limits for hydrogen concentration during transport are $2.5 \%$ by volume which corresponds to a safety factor of two.

3. Will the shipment be in vented or sealed MCOs? If the shipment is in a sealed MCO the hydrogen inventory cannot exceed $2.5 \%$ by volume during the time of transport. 
WHC-SD-SNF-DQ0-001, Rev. 0

4. Will the cask be placed in a horizontal or vertical position for transport from the $\mathrm{K}$ Basins to the staging area?

Similarly, there are related questions for the MCO design in addition to these such as:

5. What materials should the MCO be fabricated from to insure that materials compatibility and lifetime limits are well within the design margins for staging and interim storage following stabilization?

6. What are the MCO vent and possibly gas purge requirements to handle gas inventories from the radiolytic decomposition of the water present, release of hydrogen from metal hydrides and release of other sorbed gases in the fuel materials such as fission gases?

7. What is the expected continued degradation of the fuel material in the MCOs?

Additional samples will be necessary to provide the necessary data to support these decisions related to transportation and the MCO. Samples will be selected for future shipments based on results of these initial examinations.

The Characterization Plan (Abrefah 1994) considers 12 information needs for the SNF for the pathway of repackaging the K East material in closed canisters similar to $K$ West. These information needs are in general applicable to several different proposals for mitigating the identified problem and are applicable to the present Path Forward.

The initial examination of the $K$ West fuel is targeted to the following four information needs: corrosion characteristics, combustibility and pyrophoricity, size, weight, and density characteristics, and physical condition.

\subsection{DATA QUALITY OBJECTIVE STEP 3: IDENTIFY THE INPUTS}

The following data inputs are available during the preparations, loading and shipping, and examinations of the first shipments of fuel to the hot cells. A11 the in-basin activities associated with the canister movement, opening, element removal, and loading of the Single Fuel Element Containers (SFECS) will be monitored and recorded on video. The SFECs will have a special device to measure gas volume buildup for a prescribed period of time before they are shipped to the hot cells.

The condition of the fuel elements will be closely monitored during all the examination steps in the hot cells. The hot cell examinations are to be conducted in an air environment in the hot cells unless an inert gas purged environment is found necessary for certain tests in the event of pyrophoric 


$$
\text { WHC-SD-SNF-DQ0-001, Rev. } 0
$$

behavior. Planned hot cell examinations include visual examinations and photography, dimensional characterization, weight and density, metallography, and controlled atmosphere and temperature testing of selected fuel samples in a furnace.

The data to be collected are connected to the decisions to be made for transportation and the MCOs through the use of the information needs from the Characterization $\mathrm{Plan}$ in the following four logic diagrams (Figures 1 through 4). The relationship of the data being collected to the decisions to be made are discussed in detail in the following sections.

\subsection{VISUAL/VIDEO DURING IN-BASIN EXAMINATIONS}

All the in-basin activities conducted to ship the fuel element samples to the hot cells will be observed and recorded on video. There has been substantial speculation as to the condition of the fuel in the sealed canisters after prolonged storage in excess of 10 years. A corrosion inhibitor was added to the canisters after they were sealed and there have been no observations or examinations to determine the performance of the corrosion inhibitors in the sealed canisters and possibly those which have developed leaks with the basin water.

The visual examination and recorded video will have direct input to questions related to corrosion characteristics in the closed canisters with a corrosion inhibitor present. If the fuel shows extensive degradation consistent with enhanced oxidation and hydriding then the closed canister environment may have generated a larger population of degraded fuel to be handled than if the material had been stored in open canisters. Conversely, if there is minimal fuel degradation the conditions within the canisters inhibited further degradation and as such may be a good candidate for the environment in the MCOs.

The corrosion characteristics information obtained from the visual examinations in the basin provides input to the decisions for transportation related to wet versus dry shipment and indirectly to the expected hydrogen gas inventory. Similarly the visual examinations provide unique data for material compatibility issues related to the canister structural materials and data for dimensional considerations such as canister distortion and damage from reuse of canisters that would preclude a close tolerance fit between the canisters and the MCO.

The visual examinations provide information on the physical condition and integrity of the elements as we11 as their size for corresponding decisions for transportation concerning horizontal versus vertical shipments and venting during shipping.

There are areas where the data being collected overlaps more than one of the information needs related to the decisions for transportation and the MCOs. The visual examinations and corresponding video during in-basin examinations is one of these cases where the data supports three identified information needs and the related decisions shown in the three applicable logic diagrams (Figures 1,3 , and 4 ). 
Figure 1. Logic Diagram Showing the Applications of the Data Collected to the Decision for the Information Need of Corrosion Characteristics and Rate.

Decisions

- Transportation

- Wet Versus Dry

- Gas Inventory

- Vented or Sealed

- Horizontal or Vertical

- MCO's

- Materials Compatibility

- Dimensional

- Vent/Purge

- Degradation
Data Being Collected

- Visual/Video During Canister Unloading, SFEC Loading

- Gas Pressure Measurements Needs: Corrosion Characteristics and Rate

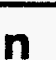

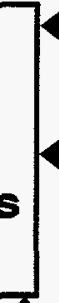

1- Visual, Photo, Video Unloading in Air Cells, Exams \& Sectioning

- Dimensional Character.

- Weight and Density

- Metallography

- Fuel Condition

- Oxidation

- Hydride (?)

- Furnace Testing 
Figure 2. Logic Diagram Showing the Application of the Data Collected to the Decisions for the Information Need of Combustibility and Pyrophoricity.

Decisions

- Transportation

- Wet Versus Dry 4

- Gas Inventory

- Vented or Sealed

- Horizontal or Vertical

- MCO's

- Materials Compatibility

- Dimensional

- Vent/Purge

- Degradation

Data Being Collected

- Visual/Video During Canister Unloading, SFEC Loading

- Gas Pressure Measurements nformation Needs:

Combustibility/ Pyrophoricity 1

Visual, Photo, Video Unloading in Air Cells, Exams \& Sectioning

- Dimensional Character.

- Weight and Density

- Metallography

- Fuel Condition

- Oxidation

- Hydride (?)

- Furnace Testing 
Figure 3. Logic Diagram Showing the Application of the Data Collected to the Decisions for the Information Need of Size/Weight and Density Characteristics.

Decisions

- Transportation

- Wet Versus Dry

- Gas Inventory

- Vented or Sealed

- Horizontal or Vertical

- MCO's

- Materials Compatibility

- Dimensional

- Vent/Purge

- Degradation

Data Being Collected

- Visual/Video During Canister Unloading, SFEC Loading

Information Needs:

Size/Weight Density Characteristics
- Gas Pressure Measurements

Ł. Visual, Photo, Video Unloading in Air Cells, Exams \& Sectioning

Dimensional Character.

Weight and Density

- Metallography

- Fuel Condition

- Oxidation

- Hydride (?)

- Furnace Testing 
Figure 4. Logic Diagram Showing the Applications of the

Data Collected to the Decisions for the Information Need of Physical Condition and Integrity.

Decisions

- Transportation

- Wet Versus Dry

- Gas Inventory

- Vented or Sealed

- Horizontal or Vertical

- MCO's

- Materials Compatibility

- Dimensional

- Vent/Purge

- Degradation
Data Being Collected

- Visual/Video During Canister Unloading, SFEC Loading

- Gas Pressure Measurements Needs: Physical Condition/ Integrity
- Visual, Photo, Video Unloading in Air Cells, Exams \& Sectioning

Dimensional Character.

- Weight and Density

- Metallography

- Fuel Condition

- Oxidation

- Hydride (?)

- Furnace Testing 
WHC-SD-SNF-DQ0-001, Rev. 0

\subsection{GAS GENERATION MEASUREMENTS}

The gas volume changes with time will be monitored in the SFEC after the fuel elements are loaded and before the SFECS are placed in the shipping cask. These volume measurements are an integral part of the safety analysis and approvals for the shipments (Stevens 1994). These measurements were selected for the shipment in the absence of data to support analyses of the expected quantities of hydrogen released during the shipments to the hot cells. The hydrogen volume concentration must stay below $2.5 \%$ to meet shipping requirements.

The hydrogen concentrations during transport is also an issue for the MCOs. The gas volume measurements will provide gross data for a single element to support the design of the shipping pathway for the materials.

The issue was raised concerning the gas pressure buildup where the elements are subjected to movement, exposure of surfaces to liquids, additional fracturing, etc., that may occur during transit and handling at the shipping and receiving sites (Miska 1994). Unfortunately it will not be possible to measure gas generation during the first shipments due to dimensional limitations at the hot cells for transfer of the SFECs from the 327 Building basin to the individual cells for examinations.

\subsection{VISUAL/VIDEO DURING HOT CELL EXAMINATIONS}

All the in-cell activities will be closely monitored for changes in sample appearance and recorded on video where appropriate. These examinations will provide sequential data to that taken in the basin during canister opening and fuel movement for shipment (Section 4.1) and supports the same information needs and decisions. Comparisons will provide initial perspectives on the effects, if any, of the transportation and handling.

These examinations provide the first opportunity to observe the behavior of the material in air after substantial underwater storage. This is analogous to what may happen in the case of a "dry" shipment, or when the material is prepared for stabilization if shipping and staging are conducted under wet conditions. An understanding of the behavior of the material after exposure to air is necessary to evaluate postulated shipping accident scenarios where the MCOs are damaged and the water leaks out and the elements are accidently exposed to air during handling or transport. In the absence of any data, even bounding cases, literature data would by necessity be used to provide a perspective on the behavior and extent of possible radioactive material release. 
WHC-SD-SNF-DQ0-001, Rev. 0

\subsection{DIMENSIONAL CHARACTERIZATION}

The physical dimensions will be measured for each of the fuel element samples shipped to the hot cells for examinations. The changes in the physical dimensions that result from either irradiation or deterioration from storage impact dimensional considerations for the MCO design. The dimensional characterization provides direct data on the physical condition and integrity of the fuel as well as the size and weight characteristics. These information needs have direct applicability in decisions for transportation related to horizontal or vertical shipments, use of sealed or vented casks and possible degradation as a result of the shipping activities as well as the direct applications to the MCO dimensional considerations.

Comparisons of the physical dimensions with the fabrication values and tolerances will provide the basis for preparing a specification or requirement on the dimension of the elements for transportation and MCO design. Element dimensions, weight, and other characteristics related to handling such as integrity may be necessary to adequately design tooling for remote handling. Special tools are being developed as part of the associated in-basin activities to retrieve samples for shipment to the hot cells. Issues related to handling badly degraded elements and expedited handling to reduce operator exposure have surfaced during the development of the tools. Similar concerns may become evident during process development if it is necessary to retrieve and handle individual elements for stabilization.

\subsection{ELEMENT WEIGHT AND DENSITY}

Characterization of the elements will include weight in air and immersion density. This data supports the information needs of size, weight, and density characteristics and physical condition and integrity in the same manner as does the dimensional characterization discussed in the previous section.

\subsection{METALLOGRAPHY}

Selected fuel samples will be removed from the fuel elements for metallographic examinations. These examinations will be focused on establishing the characteristics of the corrosion occurring in the breached and failed elements. Examinations will establish the fuel condition, extent of oxidation, and possibly hydride formation. Sample preparation may convert the hydride to a more stable oxide resulting in a loss of material for direct evaluation. Additional techniques are being evaluated that may provide indirect evidence of the presence of the hydride. The depth of oxide formation in selected samples will provide some corrosion rate estimates assuming no reacted material is lost during sample preparation and the time of initiation of the corrosion process is defined.

The information needs for corrosion characteristics and limited information on rate provides input to the decision on transportation related 
to wet versus dry, gas inventory, and vented or sealed containers. Corrosion characteristics also have direct applicability to decision related to MCO materials compatibility, dimensional considerations, and degradation during staging in the MCO if they are water filled.

Specific data on the extent and rate of oxide and hydride formation is central to the design decisions related to issues for transportation and the MCO as well as emerging questions related to behavior during staging and stabilization process optimization.

\subsection{FURNACE TESTING}

Selected samples of fuel will be placed in a controlled atmosphere furnace and heated to controlled temperatures to determine the combustion and pyrophoric properties of the material. The potential for fuel combustion in the presence of air is a major information need that is overriding to decisions related to transportation and MCO design in the areas of wet versus dry and sealed or vented shipments and whether or not to vent and or purge the MCOs.

The potential for fuel combustion is one of the major safety questions that must be adequately addressed for every operation dealing with the material after prolonged storage under water. Furnace testing is expected to establish the parameters for handling, transportation, and interim and repository storage of the fuel to mitigate the potential for fuel combustion.

If the fuel material shows little tendency for combustion in moist air at ambient temperatures it may be possible to drain the MCOs before they are shipped to the staging area. Similarly the MCOs during staging may only require limited venting and purging if any. Conversely, if the fuel material shows a high affinity for combustion in conditions expected during transportation or staging precaution must be taken to eliminate the probability of combustion. This will only be a problem for the open canisters from $K$ East. If the closed canisters in $K$ West are loaded into the MCOs with the 1 ids in place combustion will not be an issue since the fuel material will remain in the sealed canisters.

Literature data, and laboratory testing of unirradiated material would be subject to uncertainty due to differences in the irradiated material after extended storage in areas such as extent and distribution of hydrides, extent of oxide formation etc. Therefore, hot cell testing of actual $K$ Basin fuel is necessary to establish these performance parameters.

The development of the specific requirements for the furnace testing will be covered in an addendum to this DQO following an initial evaluation of the examinations data. Questions related to furnace time and temperature range, composition of the atmosphere in the test chamber, measurement accuracy etc., will be addressed in this addendum. 
WHC-SD-SNF-DQ0-001, Rev. 0

\subsection{DATA QUALITY OBJECTIVE STEP 4: DECISION BOUNDARIES}

The initial fuel shipment will be restricted to the fuel in closed canisters in the $K$ West Basin. A sampling strategy has been developed based on the appearance of the fuel material after the canisters are opened recognizing that a statistically based sampling strategy is not possible due to the large number of variables represented by the fuel in storage in $K$ West and the schedule and cost constraints of the project (Abrefah, Bergmann 1994).

\subsection{DATA QUALITY OBJECTIVE STEPS 5 AND 6: DECISION RULES AND ACCEPTABLE LIMITS ON DECISION ERROR}

A 7 imited scope DQO is being used for the initial examination of the $K$ West fuels therefore the development of a decision rule and acceptable limits on the decision error are beyond the scope of the DQO activities (Lawrence 1994).

\subsection{DATA QUALITY OBJECTIVE STEP 7: OPTIMIZE}

The examinations are being optimized by the use of a flexible sampling plan to select the samples for hot cell examinations. If the fuel is found to be severely degraded in the sealed canisters the samples removed for hot cell examinations may be significantly different than if there is minimal or no additional degradation during the sealed canister storage. Similarly information gained during each step of the examination will be utilized to obtain the most relevant information from subsequent examination steps. If for example the breached fuel element reacts with the cell atmosphere to further degrade the process will be observed and the detailed sampling of that element will be modified to account for the observed degradation.

A detailed sampling $p 1$ an was developed supplementing this DQO (Makenas 1995). This plan identifies the specific canisters to be opened and what samples will be removed for examinations.

\subsection{SAMPLE SELECTION}

The variables were identified that are expected to affect the fuel degradation during the extended underwater storage in the basins and the samples to be removed from the $K$ West Basin for the initial shipment to the hot cells were selected. 


\subsection{VARIABLES INFLUENCING FUEL DEGRADATION}

During underwater storage a number of factors have been identified that might have contributed to the degradation of the fuel stored in the basins. The factors being considered in selecting fuel samples for the characterization activities include:

1. Breached cladding: The fuel inventory contains elements whose cladding was breached during reactor discharge and/or subsequent handling. The cladding failures range from cracks to broken fuel elements. A large number of the failures occurred at the end of fuel elements due to collisions with other elements during discharge and subsequent handling in the discharge chute and basins. The fuel element end cap braze joints might have failed due to the combined effect of irradiation and subsequent corrosion in the basins. A variety of effective surface areas would be created that can influence degradation rates.

2. Storage mode: There are two major storage modes; open (K East Basin) and encapsulated ( $K$ West Basin) canisters. The open canisters include both closed and open bottoms (i.e., screen bottoms) in the $K$ East Basin. The uranium corrosion rate is strongly influenced by the storage environment. In the sealed canisters in $K$ West Basin a large number of fuel elements had portions of the fuel extending into the gas space of the canisters. This condition presents a possibility of gas phase oxidation of the fuel stored in $K$ West. Most of the $N$ Reactor Mark IV elements have the potential to be above the water level in the sealed $K$ West canisters and may have experienced vapor phase corrosion. In addition, the enclosed atmosphere could deplete oxygen (by reaction with exposed fuel) in the canister water, changing the chemistry of the water and potentially accelerating the corrosion of the fuel.

3. Irradiation history: The irradiation histories of the fuel can be divided into two classifications by the isotopic composition of ${ }^{240} \mathrm{Pu}$. Most of the fuel has been classified as either $6 \%{ }^{240} \mathrm{Pu}$ (i.e., weapon grade material with burnup of 907 and 1,098 MWD/MTU for Mark IV and Mark IA fuels, respectively) or $12 \%{ }^{240} \mathrm{Pu}$ (i.e., fuel grade material with burnup of 2,268 and 2,720 MWD/MTU for Mark IV and Mark IA fuels, respectively). Irradiation history affects the fuel degradation mechanisms mainly through fuel swelling and embrittlement. Fuel swelling and embrittlement can generate microcracks which are potential reaction sites for uranium oxidation and corrosion.

4. Fuel type and enrichment: There are three main types of spent fuel in the basin; $N$ Reactor Mark IV and Mark IA and single Pass Reactor (SPR) fuel which constitutes a minor fraction of the inventory. The fuel types vary in sizes and degree of ${ }^{235} \mathrm{U}$ enrichment. Most of the $N$ Reactor fuel stored in the basins have an enrichment of $0.947 \%$ ${ }^{235} \mathrm{U}$ with the exception of the outer tubes of the Mark IA fuel 
elements which have $1.25 \%{ }^{235} \mathrm{U}$ and a small inventory of Mark IV assemblies (outer and inner elements) with $0.71 \%{ }^{235} \mathrm{U}$. The SPR fuel primarily made in two ${ }^{235} U$ enrichments; natural $(0.71 \%)$ and $0.947 \%$. other enrichments were manufactured which included; $1.25 \%, 1.7 \%$, and $2.1 \%{ }^{235} \mathrm{U}$. Enrichment correlates with fuel burnup and thus embrittlement and its corrosion characteristics.

5. Galvanic effects during storage: Two materials were utilized for the canisters; aluminum and stainless steel. The potential galvanic coupling of zirconium and/or uranium with the storage containers may affect the degradation of the fuel. SPR fuel elements with aluminum cladding could present different corrosion characteristics.

Aluminum, for example, is reported to be anodic to uranium at the initial stages of water corrosion. The coupled uranium may have a higher corrosion rate than an uncoupled uranium.

6. Basin water quality: Over the years the water quality of the basin has varied. At one point in time chlorine was added to the basin water as a fungicide. This practice was stopped when evidence of pitting corrosion was seen on the aluminum storage canisters. The current practice is to utilize demineralized water. Since the fuel storage spans a range of time, different fuel group as have been exposed to different qualities of basin water.

7. Storage time: The length of time the fuel has been in wet storage directly affects the current condition of the fuel. Fuel with breached cladding will experience more corrosion with increased storage time. Also fuel with long storage histories have experience considerable handling, which could have mechanically damaged the fuel cladding. This has the potential of increasing the amount of metallic fuel available for corrosion.

8. Fuel assembly configuration: The $N$ Reactor fuel assembly is made of two concentric tubes held together by locking spacers. During discharge and handling the outer elements experienced much more mechanical damage than the inner tubes. It is likely that the outer elements experience more fuel degradation than the inner elements.

The selection of characterization samples from the inventory must take into account these factors and the total population of fuel stored in the basins. The large number of fuel assemblies $\left({ }^{-103,000)}\right.$ in the $K$ East and $K$ West basins and different storage modes and histories, makes a statistical sampling process impractical from the standpoint of cost and schedule. Thus, for the characterization activity to provide data that supports the decisionmaking process, a phased approach has been adopted. The initial samples will be chosen to obtain the general condition and physical properties of the fuel. Once this data has been obtained, it will be evaluated and utilized to refine the sampling for future shipments. 
Broken or breached cladding was identified as the variable considered to be of primary concern for the initial examinations of fuel from $K$ West. This was selected because it provides the pathway for the uranium and water corrosion process and corresponding material degradation. The initial fuel samples will be selected using canister loading records for broken elements and visual examinations.

\subsection{K WEST SAMPLES SELECTED FOR THE INITIAL FUEL EXAMINATIONS}

The initial samples were chosen to establish general condition and physical properties of the $K$ West SNF, using fuel assembly configuration and breached cladding as the primary selection criteria. The capacity of the shipping cask limits the size of a single shipment to the equivalent of two outer cylindrical fuel elements and one inner element. Based on these considerations and the results of visual examinations in the basins, the following types of fuel elements from $K$ West were selected for the first shipment of fuel samples for characterization:

- A broken Mark IV fuel element: Characterization of this sample will show the degree of degradation of $K$ West fuel with exposed uranium metal within the closed $K$ West canisters, and whether stabilized uranium hydride has formed in this environment. This will address assertions that the $K$ West fuel is more degraded and/or pyrophoric than the K East fuel.

- A slightly breached Mark IV fuel element with length codes S or E: Characterization of this sample will evaluate effects of limited water access to the area of corrosion and possible enhanced uranium hydride formation.

- A visually intact fuel element: Characterization of this sample will indicate whether the encapsulation of intact $N$ Reactor SNF elements in $K$ West adequately protected it from long-term degradation. The visibly intact fuel elements may contain incipient failure sites most likely in the areas of the braze that seals the end cap on the elements.

These three sample elements are expected to provide bounding information for those potential conditions of the $K$ West SNF which could affect the viability of the Path Forward for the information needs of hydride formation/ pyrophoricity, corrosion, and physical degradation. 


\subsection{REFERENCES}

Abrefah, J., D. W. Bergmann, "Spent Nuclear Fuels Sampling Strategy," WHC-SNF-SM-001, Rev. 0, December 1994.

Abrefah, J., T. A. Thornton, L. E. Thomas, F. R. Berting, S. C. Marshman, "The Characterization Plan for Hanford Spent Nuclear Fue1," PNL-10210, Rev. 0, December 1994.

Burke, S. P., Personne1 Communication, June 1994.

Fulton, J. C., Hanford Spent Nuclear Fuel Project Recommended Path Forward," WHC-EP-0830, October 1994.

Goldmann, L. H., "Personnel Communications, Draft Cask/Transport System Schedule," January 31, 1995.

Lawrence, L. A., K. S. Redus, T. A. Thornton, "Spent Nuclear Fuel Project Characterization Data Quality Objective Strategy, "WHC-EP-0795, December 1994.

Makenas, B. J., "Choices of Canisters and Elements for the First Fuel Shipment from K West Basin," WHC-SD-SNF-SM-002, Draft, February 1, 1995.

Miska, C. R., Personnel Communication, cc:Mail Message to L. A. Lawrence, WHC, December 9, 1994.

Stevens, P. F., "Safety Evaluations for Packaging for the N Reactor/Single Pass Reactor Fuel Characterization Shipments, "WHC-SD-TP-SEP-028, Rev. 0, October 1994. 


\section{DISTRIBUTION}

Number of copies

OFFSITE

1

Washington State Department of Ecology

P.0. Box 47600

Olympia, Washington 98504-7600

D. Silver

1

Washington State Department of Health Airdustrial Park

Building 5, Mail Stop LE-13

Olympia, Washington 98504-0095

A. W. Conk Tin

ONSITE

4

U.S. Department of Energy, Richland Field office

S. S. Clark

R3-81

J. L. Daily II

R3-81

G. D. Trenchard

R3-81

J. Shuen

R3-81

3

Mac Technical Services Company

G. Baston

R3-82

R. P. Denise

R3-82

J. A. Sheriff

B1-42

8

Pacific Northwest Laboratory

J. Abrefah

P7-14

R. E. Einzinger

P7-14

S. C. Marschman

P7-18

T. D. Pyecha

P7-14

J. L. Scott

$\mathrm{K} 1-22$

T. A. Thornton

P7-18

K. M. Tominey

K7-97

P. J. Turner

P7-35

1

\section{SAIC}

J. R. Honekamp 
WHC-SD-SNF-DQ0-001, Rev. 0

DISTRIBUTION (cont.)

Number of Copies

ONSITE

Westinghouse Hanford Company

D. W. Bergmann

R3-86

A. E. Bridges

B. S. Carlisle

L5-01

S. A. Chastain

X3-71

R. G. Cowan

L5-01

J. C. Fulton

R3-86

J. R. Frederickson

R3-85

E. W. Gerber

R3-86

L. H. Goldmann

R3-86

S. L. Hecht

R3-86

A. T. Kee

L. A. Lawrence

(5)

L5-01

B. J. Makenas

R. L. McCormack

R3-86

L5-01

C. R. Miska

R. P. Omberg

A. L. Pajunen

J. Perez-Carter

L5-01

R3-86

R3-86

R3-86

H5-49

A. L. Pitner

L5-01

J. P. Schmidt

L5-01

P. K. Shen

$\times 3-73$

D. W. Smith

R3-87

D. J. Trimble

R3-85

J. W. Weber

L5-01

M. J. Wiemers

L5-01

OSTI (2)

R3-86

Central Files

L8-07

L8-04 